\title{
Modification of Egyptian Bagasse Kraft Pulping Using Yield - increasing Additives I-Effect on Chemical Properties
}

\author{
M.B. Ghazy", M.S. Thabet, F. Abdel-Hai and M.E. Owda \\ Chemistry Department, Faculty of Science, Al-Azhar University, \\ Nasr city, Cairo, Egypt.
}

\begin{abstract}
R AGASSE is one of the potential raw materials for pulp in Egypt. So, our target is to improve the chemical properties of Kraft pulp using yield- increasing additives as anthraquinone (AQ), polysulfide (PS) and sodium borohydride $\left(\mathrm{NaBH}_{4}\right)$. The effect of the bagasse to liquor ratio $\mathrm{B} / \mathrm{L}$ ratio was also examined. The yield gains for $\mathrm{AQ}, \mathrm{PS}$, $\mathrm{NaBH}_{4}$, AQ-PS and AQ-NaBH 4 were $4.73 \%, 6.46 \%, 2.99 \%, 12.15 \%$ and $4.05 \%$, respectively for $1: 4 \mathrm{~B} / \mathrm{L}$ ratio. While the yield gains at $1: 10 \mathrm{~B} / \mathrm{L}$ ratio were $1.42 \%, 2.65 \%, 5.2 \%, 6.9 \%$ and $5.3 \%$, respectively. Combination of AQ-PS gave synergistic effect. AQ, $\mathrm{NaBH}_{4}$ and $\mathrm{AQ}-\mathrm{NaBH}_{4}$ reduced the kappa number by $7 \%, 14 \%, 9 \%$, $4.48 \%, 40.3 \%$ and $5.95 \%$ for $1: 4$ and $1: 10 \mathrm{~B} / \mathrm{L}$ ratios, respectively. More dissolution of lignin was promoted at higher $\mathrm{B} / \mathrm{L}$ ratio. All additives preserved the carbohydrate yield more than the Kraft one, and showed higher delignification selectivity except for PS.
\end{abstract}

Keywords: Egyptian bagasse, Kraft pulp, Modified kraft pulp, AQ, $\mathrm{NaBH}_{4}, \mathrm{PS}$ and Yield-increasing additives.

The use of agro-fiber wastes in paper production is beneficial in terms of environmental and socio-economic aspects. The production of non-wood plant pulps has increased rapidly ${ }^{(1)}$ and today, several non-wood fiber resources are commercially utilized to manufacture chemical pulp and paper products in China, India, Latin America, Africa, Middle East and Turkey ${ }^{(2)}$. At present, some agricultural residues such as wheat and rice straws, sorghum stalks and some annual plants such as hemp and jute are used as raw materials for pulp and paper production ${ }^{(1,2)}$. Moreover, numerous studies have been performed to introduce new lignocellulosic fiber resources such as cotton stalks and bagasse for pulp and paper industries ${ }^{(3-5)}$.

Pulping yield depends on some factors such as the modification of the chemical reactions and the composition of the raw material. Thus the paper industry has recently been interested in taking advantage of an environmentally friendly process involving utilizing boron compounds in pulping processes ${ }^{(6)}$. To counteract the yield losses; due to polysaccharides degradation and lignin dissolution; several studies and trials were done to investigate the effect of

*Corresponding author :Ghazymbm@hotmail.com 
addition of polysulfide, anthraquinone and borohydrate on kraft cooking. Further studies ${ }^{(6)}$ which aimed at increasing the yield have largely focused on modifying the Kraft process with multiple liquor injection and impregnation techniques in order to minimize the alkali degradation of cellulose and hemicelluloses. With better understanding of the chemistry of the kraft process as well as the mechanisms for degradation and loss of polysaccharides in alkali solutions, attention is now mainly focused on developing ways of stabilizing the cellulose and hemicelluloses against alkaline attack thereby, leading to higher pulp yields. Stabilization of the polysaccharides against alkali degradation occurs with conversion of carbonyl groups with a reducing or an oxidizing agent $^{(6)}$. It has been observed that addition of end group stabilizers (such as AQ and $\mathrm{NaBH}_{4}$ ) decreases significantly the peeling-to-stopping rate constants ratio ${ }^{(7)}$. Furthermore, addition of pulping additives (such as anthraquinone, polysulfide or sodium borohydride) to cooking liquor increases pulp yield through greater retention of hemicelluloses ${ }^{(8)}$. $\mathrm{NaBH}_{4}$ particularly is an effective chemical for selective delignification ${ }^{(9)}$. It causes reduction of carbonyl group located on the end group of cellulose to hydroxyl group during the cooking and thus stops the probable peeling reaction. Which can occur in both cellulose and hemicelluloses ${ }^{(6)}$. The major effect of borohydride is to prevent the acceleration of glucomannan removal that otherwise occurs at $100^{\circ} \mathrm{C}^{(8)}$. Polysulfide pulping results in substantial yield gain which is brought about by oxidation of aldehyde end groups in carbohydrate chains to aldonic acids during cleavage, thereby stabilizing aldehyde end groups against further peeling ${ }^{(10,11)}$. The yield increase in PS pulping is proportional to the PS added to the cook ${ }^{(12)}$.

The aim of this study is to examine the effect of anthraquinone, polysulfide and sodium borohydride as well as the effect of bagasse to liquor ratio on the chemical properties of Egyptian bagasse Kraft pulping

\section{Materials}

\section{Materials and Methods}

The depithed bagasse used in this study was received from Masr-Edfu pulp mill at Aswan-Egypt.

\section{Chemicals}

Sodium hydroxide $(\mathrm{NaOH})$ and anthraquinone $(\mathrm{AQ})$ were obtained from EL-Naser Pharmaceutical Chemical Company, Egypt. Sodium sulfide $\left(\mathrm{Na}_{2} \mathrm{~S}\right)$ and Sodium borohydride $\left(\mathrm{NaBH}_{4}\right)$ were obtained from Oxford Laboratory Reagent (India). Sodium chlorite and sulfur were obtained from AL-gomhorya Pharmaceutical Chemical Company, Egypt.

\section{pulping}

Kraft pulping is the dominant chemical pulping process in the world, it uses $\mathrm{NaOH}$ and $\mathrm{Na}_{2} \mathrm{~S}$. For each experiment, $10 \mathrm{~g}$ oven dry bagasse was cooked in $250 \mathrm{ml}$ stainless steel autoclave at $170{ }^{0} \mathrm{C}$ for $150 \mathrm{~min}$ after reaching the

Egypt. J. Chem. 57, No. 5,6 (2014) 
temperature in $60 \mathrm{~min}$. The cooks were made at $20 \%$ alkali charges and $20 \%$ sulfidity. The bagasse-to-liquor ratio for all cooks $(\mathrm{g} / \mathrm{ml})$ were 1:4 and 1:10. The autoclaves after being purged with nitrogen, were sealed and heated in an oil bath in which the temperature was raised from the ambient to the desired temperature. Kraft cooks were prepared using $\mathrm{NaOH}+\mathrm{Na}_{2} \mathrm{~S}(\mathrm{~K})$ or by adding $0.1 \%$ AQ (based on o.d. bagasse), $1 \%, 2 \%$ and $3 \% \mathrm{NaBH}_{4}$ (based on o.d. bagasse), $0.1 \% \mathrm{AQ}+3 \% \mathrm{NaBH}_{4}, 3 \% \mathrm{PS}$ (based on o.d. bagasse), and $0.1 \% \mathrm{AQ}$ $+3 \%$ PS. All of these additives were added to the autoclaves along with the bagasse. At the end of the pulping, pressure was reduced to atmospheric pressure and then the produced pulp was disintegrated, washed with tap water till free of black liquor and then air dried. Every experiment was repeated and mixed well to get enough pulp for chemical analysis. The $\alpha$-cellulose, yield, ash, and lignin contents of pulp samples were determined according to Tappi T203, T210, T211 and T222, respectively. While, holocellulose content was determined according to wise et al. ${ }^{(13)}$ and kappa number was calculated from the equation:

$$
\text { Klason lignin }=\text { kappa number } \quad \mathrm{x} \quad 0.15 \quad \text { Tappi-T236 }
$$

The values of chemical analysis were duplicated to ensure good results.

\section{Results and Discussion}

TABLE 1. Chemical constitution of bagasse.

\begin{tabular}{|c|c|c|c|}
\hline Holocellulose \% & $\boldsymbol{\alpha}$-cellulose \% & Lignin \% & Ash content \% \\
\hline 78 & 59 & 20 & 1.75 \\
\hline
\end{tabular}

Bagasse consists of holocellulose ( $\alpha$-cellulose + hemicellulose), lignin and ash .

\section{Pulping yield}

One of the disadvantages of Kraft pulping is the low pulp yield because Kraft chemicals are not selective for lignin and large amount of hemicelluloses are dissolved in the strong alkaline environment especially in the initial phase of cooking. Because pulp yield is highly desirable so, our target, as well as many researchers (14-17), is focusing on increasing yield by protecting the carbohydrates (mostly hemicelluloses) from degradation and improving fiber strength by modification of the pulping process using yield - increasing additives such as anthraquinone (AQ), sodium borohydride $\left(\mathrm{NaBH}_{4}\right)$ and polysulfide (PS).These additives stabilize the reducing ends of carbohydrates against peeling either by oxidation to carboxylic acid end group as in case of AQ and PS ${ }^{(18)}$ or by reduction of carbonyl groups to hydroxyl groups using $\mathrm{NaBH}_{4}{ }^{(15,19)}$. Chemical analysis data are compiled in Table 2 while the effect of additives on percentage yield is graphically represented in Fig. 1\&2 . Addition of AQ to the cooking liquor for $\mathrm{B} / \mathrm{L}$ ratios of $1: 4$ and 1:10 resulted in increased yield by $4.73 \%$ and $1.42 \%$, respectively due to increasing the cellulose yield 
and, to a lower extent, glucomannan ${ }^{(15)}$ because AQ stabilizes the carbohydrates from further degradation. Different authors ${ }^{(15,16,20-26)}$ proved that AQ increases the yield and accelerates the delignification rate due to its dual effect. Similarly, using $3 \%$ polysulfide (PS) in Kraft cooking increased the pulp yield by $6.46 \%$ and $2.65 \%$ for $\mathrm{B} / \mathrm{L}$ ratios $1: 4$ and $1: 10$, respectively. This trend is in agreement with the findings of Cöpür and Tozluoglu ${ }^{(15)}$ and Jiang ${ }^{(10)}$. This effect of PS is mainly as a result of increasing the retention of hemicellulose, especially glucomannan which dissolves in early stage and almost completely during kraft cooking followed by dissolution of xylan ${ }^{(27)}$. Landmark ${ }^{(18)}$ claimed that the PS stabilizes the polysaccharides against peeling reactions by oxidation of end group and the stabilization of hemicellulose begins early at $90{ }^{\circ} \mathrm{C}$ which is fast at the beginning then decreases quickly. Simultaneous addition of $0.1 \%$ AQ and 3\%PS resulted in a relative yield increase of about $12.15 \%$ and $6.19 \%$ for $1: 4$ and $1: 10 \mathrm{~B} / \mathrm{L}$ ratios, respectively. This is considerably higher than the yields observed from independent addition of either of the additive. This synergistic effect of AQ and PS has been observed previously ${ }^{(10,17,18,28)}$.

TABLE 2. Chemical analysis of pulp samples .

\begin{tabular}{|c|c|c|c|c|c|c|c|c|c|c|c|c|}
\hline Method & \multicolumn{2}{|c|}{ Yield \% } & \multicolumn{2}{|c|}{ Kappa no. } & \multicolumn{2}{|c|}{$\begin{array}{c}\text { Viscosity } \\
\text { C.Pa }\end{array}$} & \multicolumn{2}{|c|}{$\begin{array}{c}\text { Holocellulose } \\
\%\end{array}$} & \multicolumn{2}{|c|}{$\alpha$-cellulose \% } & \multicolumn{2}{|c|}{$\begin{array}{c}1 \% \mathrm{NaOH} \\
\text { solubility }\end{array}$} \\
\hline B:L ratio & $1: 4$ & $1: 10$ & $1: 4$ & $1: 10$ & $1: 4$ & $1: 10$ & $1: 4$ & $1: 10$ & $1: 4$ & $1: 10$ & $1: 4$ & $1: 10$ \\
\hline Kraft (K) & 57.77 & 56.50 & 33.33 & 22.33 & 11.84 & 12.80 & 91.80 & 94.25 & 70.60 & 70.90 & 11.40 & 11.05 \\
\hline $\begin{array}{l}\text { K-0.1\% } \\
\text { AQ }\end{array}$ & 60.50 & 57.30 & 31.00 & 21.33 & 12.20 & 12.98 & 94.25 & 96.87 & 71.40 & 71.00 & 10.50 & 10.60 \\
\hline K- $1 \% \mathrm{BH}$ & 58.41 & 58.12 & 30.00 & 20.00 & 11.86 & 13.66 & 94.50 & 96.50 & 72.15 & 72.50 & 10.60 & 9.10 \\
\hline K- $2 \%$ BH & 59.36 & 59.00 & 28.67 & 16.00 & 11.96 & 13.74 & 94.90 & 97.00 & 72.50 & 73.15 & 10.30 & 9.00 \\
\hline К-3\% BH & 59.50 & 59.44 & 29.47 & 13.33 & 12.26 & 15.02 & 95.73 & 97.60 & 73.15 & 74.00 & 10.00 & 7.75 \\
\hline $\begin{array}{l}\mathrm{K}-3 \% \mathrm{BH} \\
+\mathbf{0 . 1 \%} \mathrm{AQ}\end{array}$ & 60.11 & 59.50 & 30.33 & 21.00 & 12.02 & 12.16 & 94.60 & 94.90 & 72.55 & 72.20 & 9.35 & 8.40 \\
\hline K-3\% PS & 61.50 & 58.00 & 52.60 & 32.00 & 12.35 & 14.28 & 93.00 & 94.53 & 70.80 & 71.00 & 11.30 & 10.15 \\
\hline $\begin{array}{l}\text { K-3\% PS } \\
+0.1 \% \text { AQ }\end{array}$ & 64.79 & 60.00 & 43.33 & 30.60 & 12.50 & 14.40 & 93.40 & 95.50 & 70.95 & 71.20 & 10.90 & 11.15 \\
\hline
\end{tabular}

Egypt. J. Chem. 57, No. 5,6 (2014) 


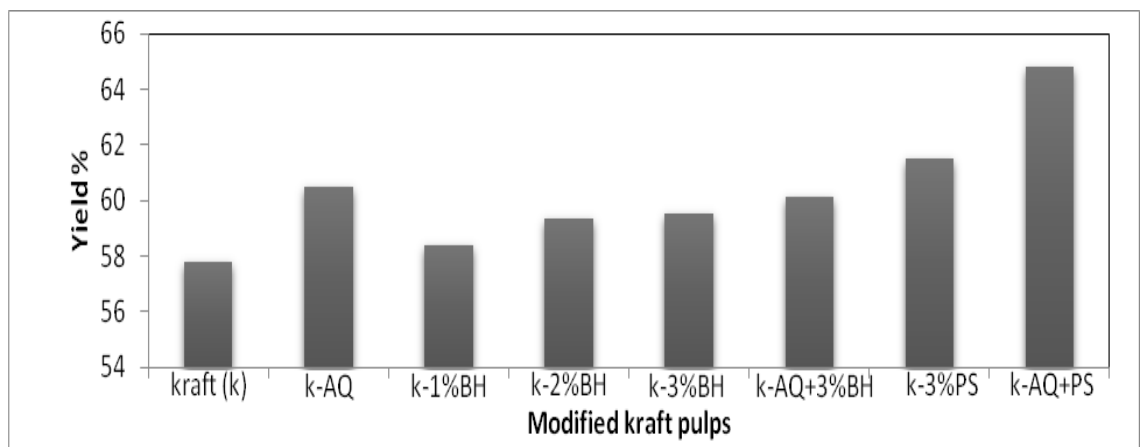

Fig. 1. Effect of additives on the yield \% at 1:4 $\mathrm{B} / \mathrm{L}$ ratio.

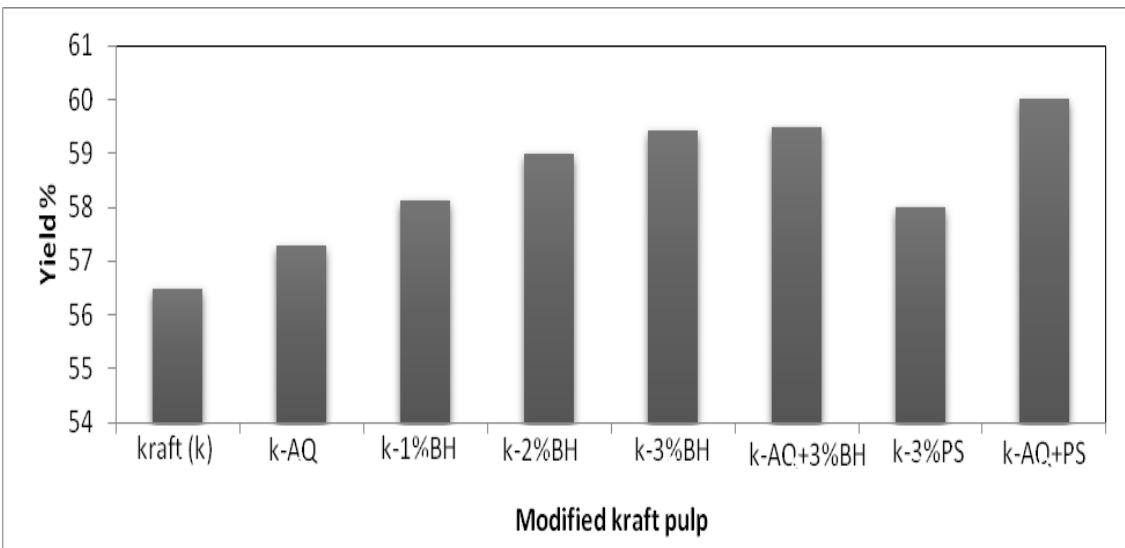

Fig. 2. Effect of additives on the yield $\%$ at $1: 10 \mathrm{~B} / \mathrm{L}$ ratio.

Our results are in a good agreement with the synergistic effect reported in literature $^{(29-32)}$. One possible mechanism by which this effect occur is that PS may participate in the AHQ-lignin and AQ-carbohydrate redox system ${ }^{(33)}$. Increasing the yield gain for 1:4 than $1: 10 \mathrm{~B} / \mathrm{L}$ ratios in case of Kraft-PS or Kraft-AQ-PS may be due to increasing polysulfide concentration consequently, increasing the stabilization of polysaccharides ${ }^{(17)}$.

Figure 3 shows that the relative yield increases with increasing concentration of $\mathrm{NaBH}_{4}$ at both $\mathrm{B} / \mathrm{L}$ ratios of 1:4 and 1:10. At low concentrations however, the additive seems to be more effective at $\mathrm{B} / \mathrm{L}$ ratio of $1: 10$. This trend was confirmed by several studies ${ }^{(14,15,19,20,34-37)}$. Our data are in agreement with findings of Akgül et al. ${ }^{(34)}$ who claimed that, increasing in yield is due to carbohydrates' preserving mechanism of $\mathrm{NaBH}_{4}$ where, Kraft- $\mathrm{NaBH}_{4}$ better preserved the carbohydrate chains and improved the pulp viscosity through the lower kappa number. Borohydride prevents the acceleration of glucomannan removal. 


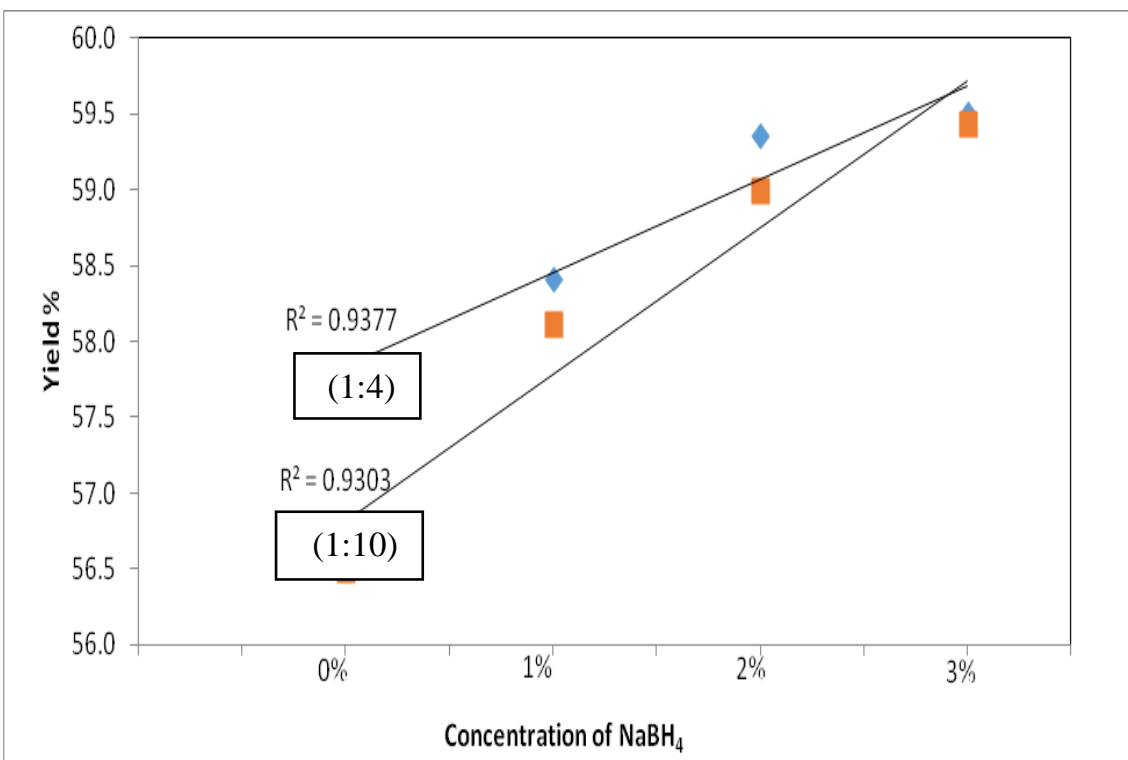

Fig. 3. The relation between percentage yield and concentration of $\mathrm{NaBH}_{4}$ at 1:4 and 1:10 $\mathrm{B} / \mathrm{L}$ ratios, respectively.

\section{Delignification}

The total lignin in pulp is the sum of insoluble lignin (klason lignin) and acid soluble lignin. Addition of $0.1 \%$ AQ to the cooking liquor decreased the kappa number by $7 \%$ and $4.48 \%$ at $1: 4$ and $1: 10 \mathrm{~B} / \mathrm{L}$ ratio, respectively, which refers to increasing the rate of delignification by addition of AQ because it facilitates $\beta$-ether cleavage producing lower molecular weight lignin fragments through its redox cycle. Several authors ${ }^{(10,38-40)}$ showed a reduction in kappa number $(7.07 \%-15 \%)$ when $0.1 \%$ AQ was used in Kraft pulping. It can be concluded that pulps with lower kappa numbers could be achieved when AQ is added to Kraft pulping specially in case of $1: 10 \mathrm{~B} / \mathrm{L}$ ratio. Generally, polysulfide pulping increased the kappa number. Our data are in accordance with Cöpür and Tozluoglu ${ }^{(15)}$ who mentioned that if low kappa numbers are desired with polysulfide pulping the active alkali should be increased because polysulfide sulfur reacts with some hydroxide and oxidizes organic materials resulting in a reduction in hydroxide ions in white liquor and consequently a reduction in lignin delignification. Another studies ${ }^{(41-43)}$ noted that the kappa number of polysulfide pulps was higher compared to the Kraft method. On the other hand, several authors ${ }^{(10,17,31,44)}$ indicated that polysulfide pulps gave lower kappa numbers than that of corresponding Kraft pulp. Anyway, the effect of polysulfide pulping on kappa number is a contentious issue.

The presence of sodium borohydride in Kraft pulping affect the rate of delignification in both $1: 4$ and $1: 10 \mathrm{~B} / \mathrm{L}$ ratios where $1 \%, 2 \%$ and $3 \% \mathrm{NaBH}_{4}$ and $0.1 \% \mathrm{AQ}-3 \% \mathrm{NaBH}_{4}$ reduced the kappa number by $10 \%, 11.52 \%, 14 \%$ and $9 \%$ for $1: 4 \mathrm{~B}: \mathrm{L}$ ratio and by $10.4 \%, 28.35 \%, 40.30 \%$ and $5.95 \%$ in case of $1: 10$

Egypt. J. Chem. 57, No. 5,6 (2014) 
$\mathrm{B} / \mathrm{L}$ ratio compared to the main Kraft pulp, respectively. These results indicated a linear relation (Fig. 4) between pulp yield and kappa number with strong regression specially for $1: 10 \mathrm{~B} / \mathrm{L}$ ratio as also observed earlier ${ }^{(31,45)}$ for kraft$\mathrm{NaBH}_{4}$ pulps. More dissolution of lignin was obtained for higher $\mathrm{B} / \mathrm{L}$ ratio because in the high liquor to wood L/W ratio cooks wood components could easily diffuse and remain in the liquor, while in the low L/W ratio cooks a certain fraction of dissolved components reabsorbed on the fibers (46). Joachimiak et al. ${ }^{(47)}$ claimed that in the higher $\mathrm{L} / \mathrm{W}$ ratio the higher value of extracted substances could be gained. Increasing the concentration of $\mathrm{NaBH}_{4}$ decreased the kappa number which was assured by Istek and Gonteki ${ }^{(35)}$ who found that increasing $\mathrm{NaBH}_{4}$ from $1 \%$ to $3 \%$ for Kraft cook reduced the kappa number due to acceleration of delignification. Tutus et al. ${ }^{(48)}$ reported also a reduction in kappa number for $\mathrm{NaBH}_{4}$-kraft cooking of cotton stalks.

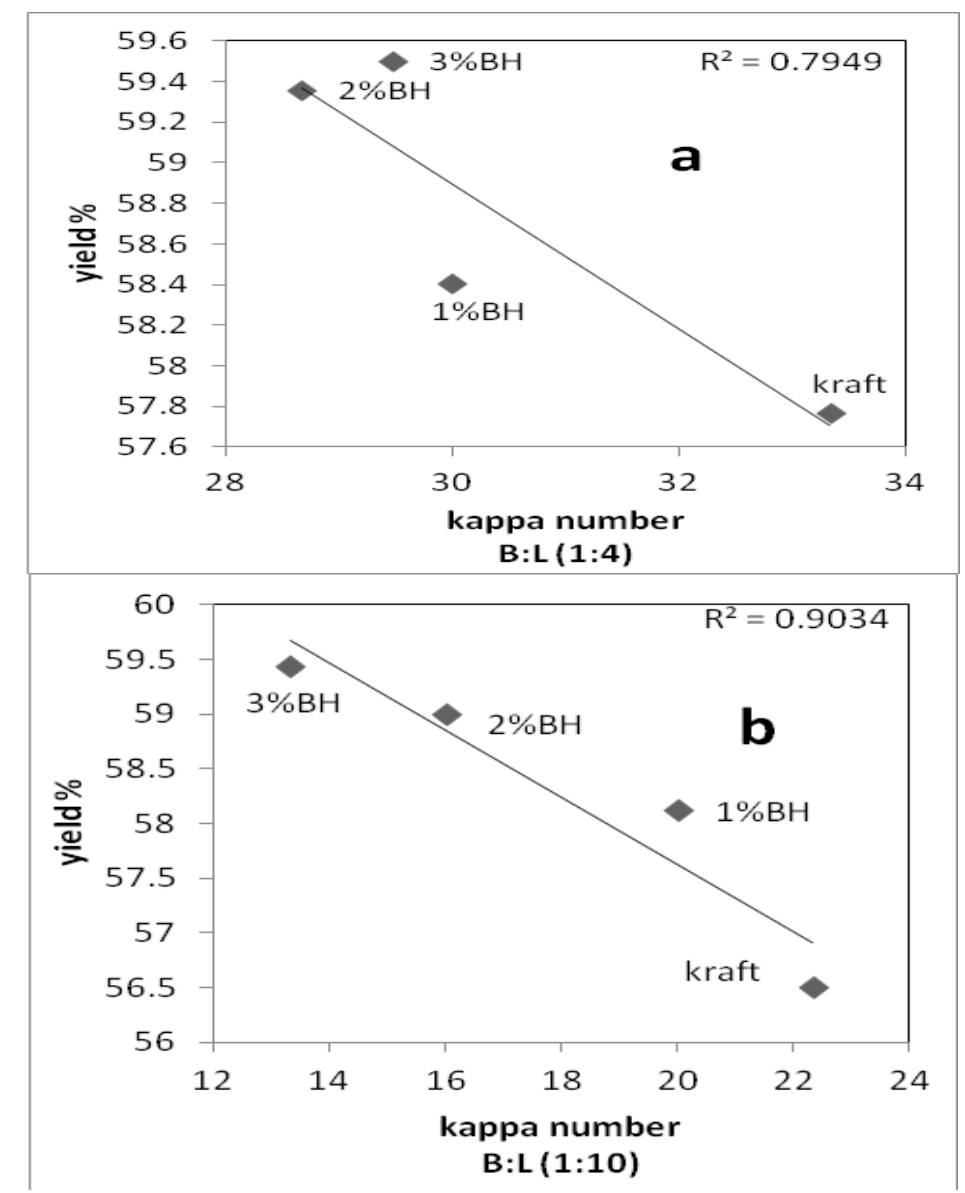

Fig. 4. Effect of sodium borohydride concentration on the relation between yield\% and kappa number of Kraft pulps for $1: 4$ and 1:10 B/L ratios.

Egypt. J. Chem. 57, No. 5,6 (2014) 
In a trial to explore the effect of combination $0.1 \% \mathrm{AQ}-3 \% \mathrm{NaBH}_{4}$ on $\mathrm{kraft}$ cooking, improving the yield by $4.05 \%$ and $5.31 \%$ and reducing kappa number of resulting pulp by $9 \%$ and $5.96 \%$ for $1: 4$ and $1: 10 \mathrm{~B} / \mathrm{L}$ ratios, respectively was observed.

\section{Viscosity of pulps}

Viscosity measurements are usually determined to evaluate the degradation of cellulose in cooking and bleaching. Introducing AQ and PS in kraft pulping resulted in pulps with higher viscosities indicating that addition of these additives decreased cellulose degradation in pulping.

PS or combination of PS-AQ gave the most favorable effect on pulp viscosity (except $3 \% \mathrm{NaBH}_{4}$ for higher $\mathrm{B} / \mathrm{L}$ ratio) compared to the other pulps in which they increase pulp viscosity by $4.31 \%, 5.57 \%$ and $11.56 \%, 12.5 \%$ for $1: 4$ and $1: 10 \mathrm{~B} / \mathrm{L}$ ratios, respectively. Improving the viscosity by these additives preserved the degree of polymerization of the cellulose chains which resulted in higher viscosity by increasing the percentage of carbohydrate yield. Our data is in accordance with the literature ${ }^{(14,19,34,37,44,49,50)}$. The results pointed out that $\mathrm{NaBH}_{4}$ preserved the carbohydrate chains and improved the viscosity of the pulps through to the lower kappa number ${ }^{(14,34)}$. Increasing the rate of $\mathrm{NaBH}_{4}$ from $1 \%$ to $3 \%$ improved the beneficial effect on pulp viscosity as shown in Fig. 5.The significant effect of the higher $1: 10 \mathrm{~B} / \mathrm{L}$ ratio showing acceleration in delignification and carbohydrate preservation resulting in higher viscosity.

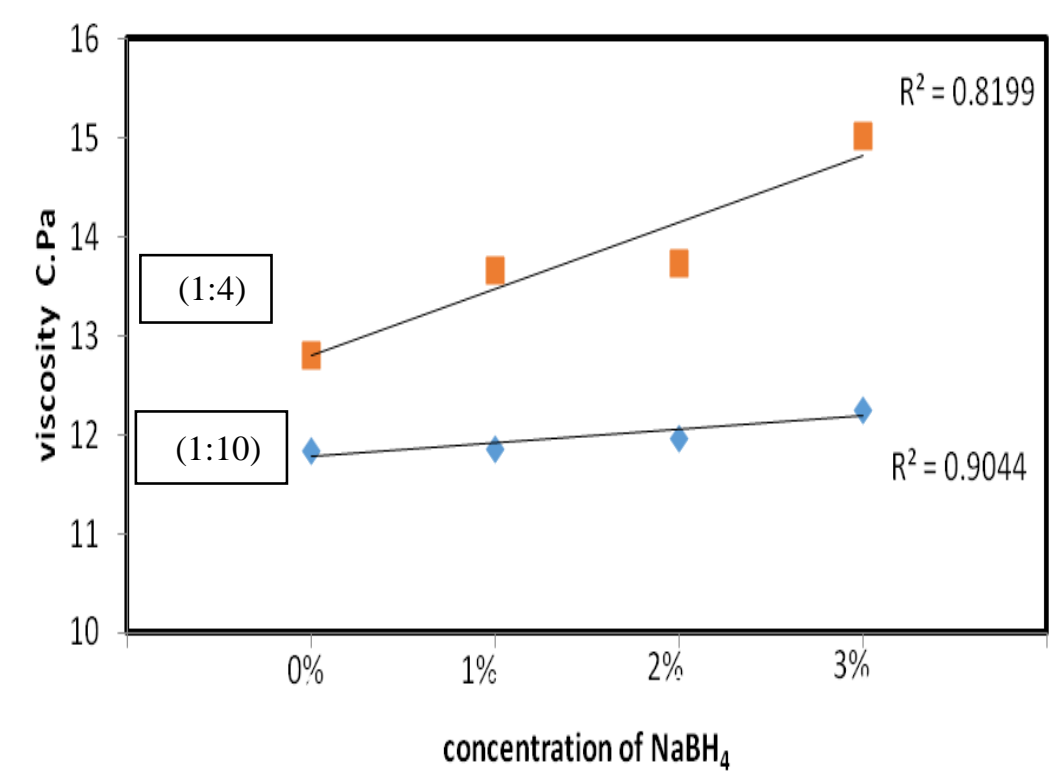

Fig. 5. The relation between viscosity and concentration of $\mathrm{NaBH}_{4}$ for $1: 4$ and 1:10 B:L ratios.

Egypt. J. Chem. 57, No. 5,6 (2014) 


\section{Holocellulose and $\alpha$-cellulose of pulps}

The reducing ends in carbohydrates (mostly hemicellulose) can be stabilized, and thus less peeling occurs, by using AQ, PS and $\mathrm{NaBH}_{4}$ during pulping. This can be remarked by the determination of holocellulose and $\alpha$ cellulose as indication of polysaccharides and cellulose, respectively. AQ, PS and $\mathrm{NaBH}_{4}$ improved the holocellulose and $\alpha$-cellulose in kraft pulp samples by protecting carbohydrates from degradation. $\mathrm{NaBH}_{4}$ has the highest protecting effect which appears through the higher values of holocellulose and $\alpha$-cellulose. Increasing the rate of $\mathrm{NaBH}_{4}$ in both $\mathrm{B} / \mathrm{L}$ ratios increased the holocellulose and $\alpha$-cellulose content of kraft pulp samples due to increasing the protecting effect of $\mathrm{NaBH}_{4}$ which assured from the good regression of the straight line relationship (Fig.6). Our data are compatible with Tutus et al. ${ }^{(19)}$ who used these additives in Kraft pulping of cotton stalks. Samples of 1:10 B/L ratio showed higher values of holocellulose and $\alpha$-cellulose contents which may also refer to increasing the protecting effect of these additives.

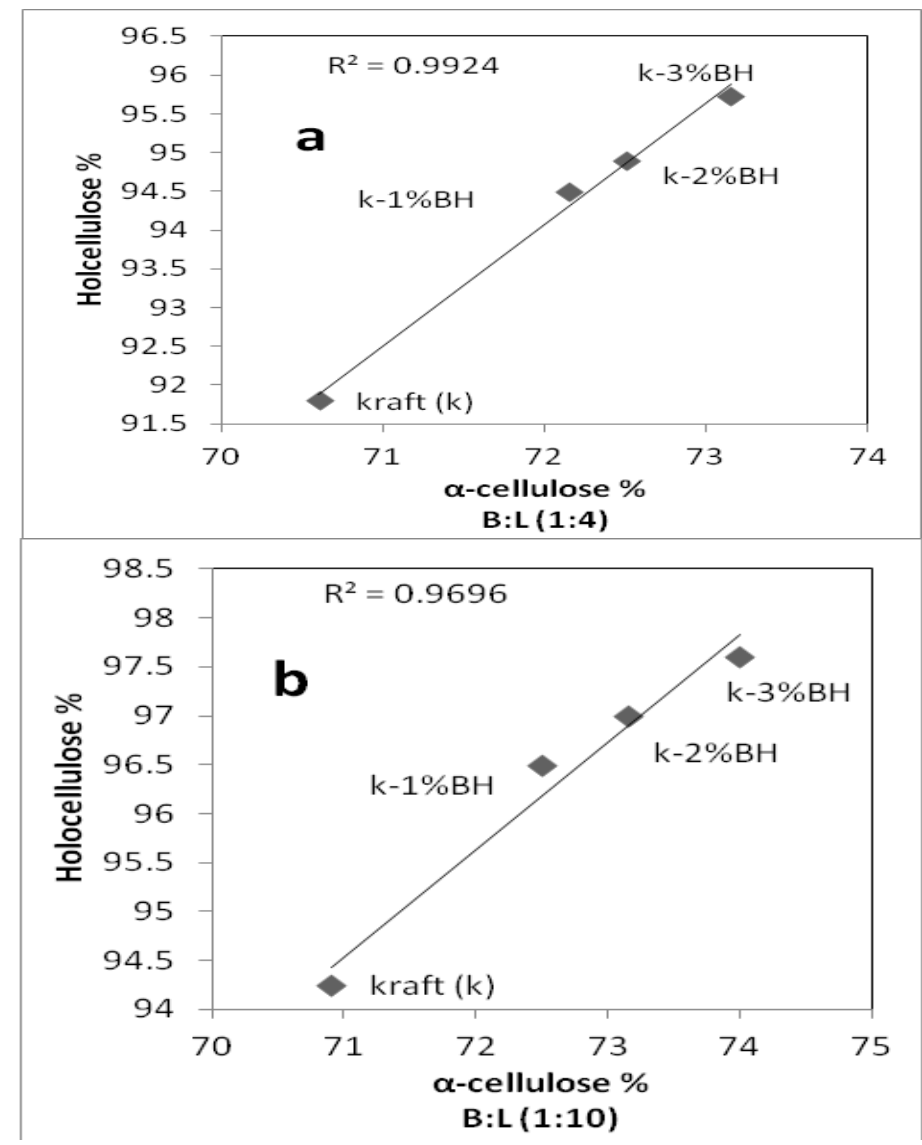

Fig. 6. Effect of sodium borohydride concentration on the relation between holocellulose \% and $\alpha$-cellulose \% for $1: 4$ and $1: 10 \mathrm{~B} / \mathrm{L}$ ratios. 
$1 \% \mathrm{NaOH}$ solubility of pulps

Hot $1 \% \mathrm{NaOH}$ extracts low molecular weight carbohydrates consisting mainly of hemicelluloses and degraded cellulose in wood and pulp. All additives showed lower values (except PS-AQ for 1:10 B/L ratio) than kraft pulp due to the carbohydrate preserving effect of these additives while, the higher 1:10 B:L ratio showed much lower values for AQ and $\mathrm{NaBH}_{4}$. Generally, PS and PS-AQ had higher values than AQ or $\mathrm{NaBH}_{4}$ which may be due to the higher lignin content. As expected, increasing the level of $\mathrm{NaBH}_{4}$ improved the carbohydrate protection consequently lowered the alkali solubility values of the produced pulps as shown in Fig. 7 which is confirmed by the strong regression of straight lines.

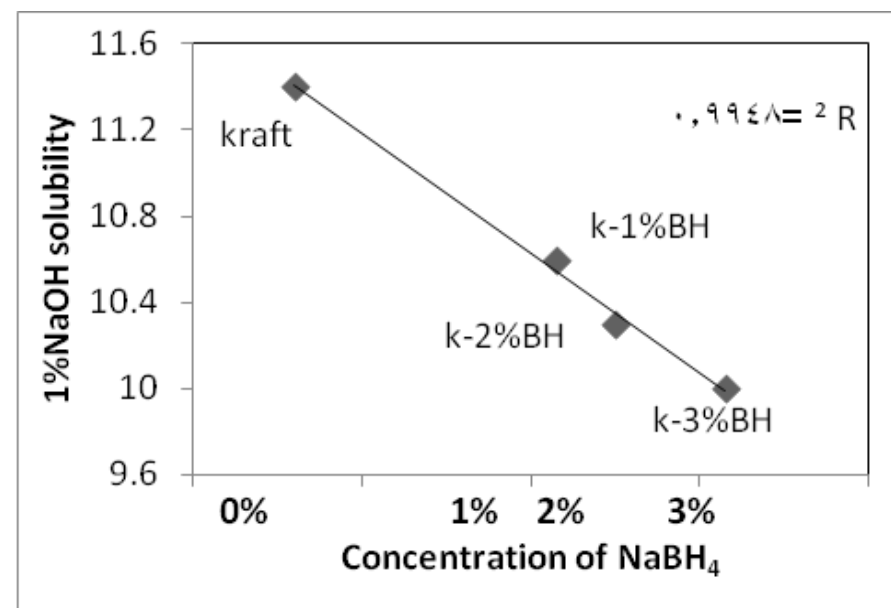

(1:4)

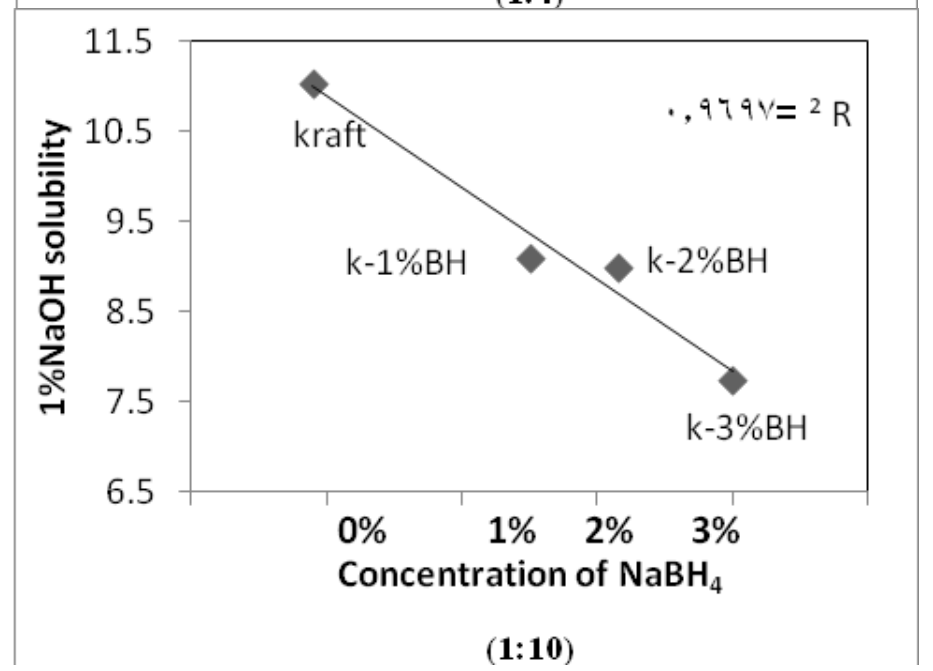

Fig. 7. Effect of sodium borohydride concentration on the alkali solubility of modified kraft pulps for 1:4 and 1:10 $\mathrm{B} / \mathrm{L}$ ratios.

Egypt. J. Chem. 57, No. 5,6 (2014) 


\section{Delignification selectivity}

The delignification selectivity is defined as the ratio of dissolved lignin to dissolved carbohydrates. It was calculated in Table 3 as mentioned by Biswas et al. ${ }^{(50)}$.The amount of lignin removed by AQ or $\mathrm{NaBH}_{4}$ is higher than that of Kraft pulp in both $\mathrm{B} / \mathrm{L}$ ratios due to the delignification effect of these additives while PS retarded it. On the other hand, the carbohydrate loss was decreased with AQ, PS and $\mathrm{NaBH}_{4}$ addition. This resulted in higher selectivity ratio of Kraft-AQ, Kraft-AQ-PS, Kraft- $\mathrm{NaBH}_{4}$ and Kraft -AQ-NaBH $\mathrm{H}_{4}$ for both $\mathrm{B} / \mathrm{L}$ ratios compared to Kraft one. The selectivity ratio increased by increasing the level of $\mathrm{NaBH}_{4}$ as observed from the strong regression for the straight lines of selectivity ratio and borohydride concentration (Fig.8). All additives showed higher carbohydrate yield than kraft pulp which may be due to a retardation of alkaline peeling reactions.

TABLE 3. Delignification selectivity of modified kraft pulps for both $1: 4$ and 1:10 B:L ratios.

\begin{tabular}{|c|c|c|c|c|c|c|c|c|c|}
\hline$\sum^{\frac{2}{2}}$ & 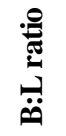 & 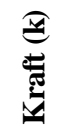 & $\frac{\substack{0 \\
0}}{\frac{0}{0}}$ & $\frac{8}{2}$ & ஸั & ֻृ & $\underset{v}{\infty}+\frac{0}{0}$ & $\begin{array}{l}2 \\
2 \\
0 \\
\ddot{1}\end{array}$ & 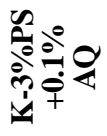 \\
\hline \multirow{2}{*}{$\begin{array}{c}\text { selectivity } \\
\text { ratio }\end{array}$} & $1: 4$ & 0.72 & 0.82 & 0.75 & 0.79 & 0.81 & 0.80 & 0.64 & 0.89 \\
\hline & $1: 10$ & 0.75 & 0.79 & 0.82 & 0.88 & 0.93 & 0.86 & 0.70 & 0.84 \\
\hline
\end{tabular}

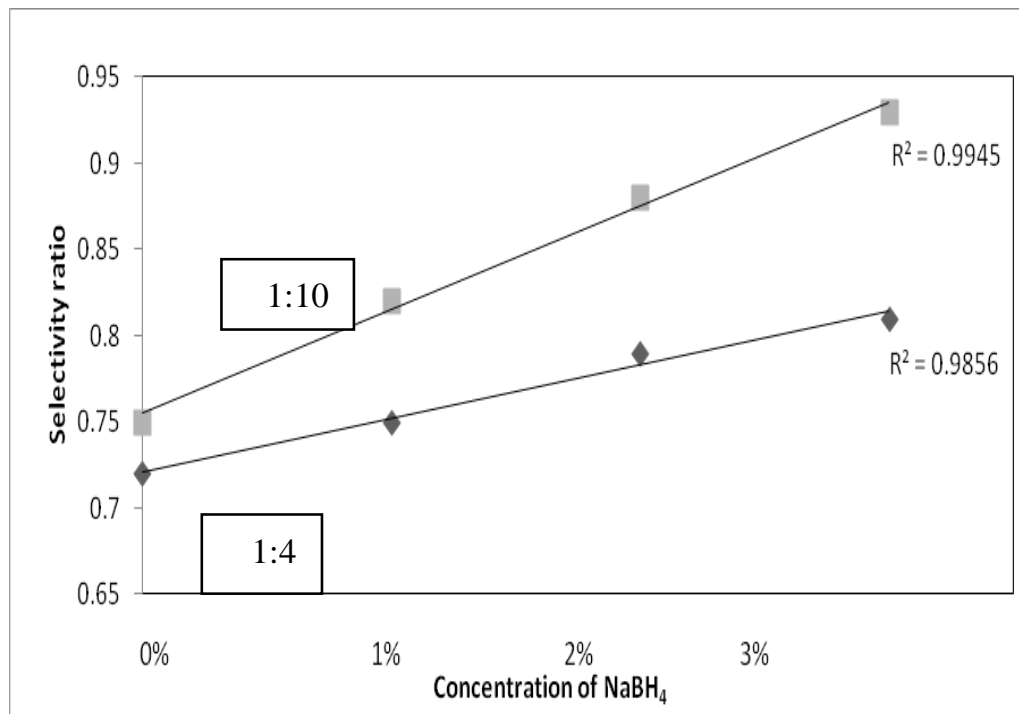

Fig. 8. The relation between selectivity ratio and concentration of modified kraft$\mathrm{NaBH}_{4}$ pulps for 1:4 and 1:10 B:L ratios.

Egypt. J. Chem. 57, No. 5,6 (2014) 


\section{Conclusion}

Egyptian bagasse kraft pulp can be modified using yield-increasing additives. Addition of anthraquinone, polysulfide and sodium borohydride significantly increased the pulp yield especially when AQ and PS are used together due to their synergistic effect. AQ and $\mathrm{NaBH}_{4}$ were observed to decrease kappa number while PS or PS-AQ increased it. With the exception of $\mathrm{AQ}-\mathrm{NaBH}_{4}$ at 1:10 $\mathrm{B} / \mathrm{L}$ ratio, all the additives showed higher viscosities than Kraft pulps. The additives appear to improve holocellulose and $\alpha$-cellulose of pulp samples by protecting carbohydrates from degradation. On the other hand, increasing the concentration of $\mathrm{NaBH}_{4}$ increased the yield, viscosity, holocellulose and $\alpha$-cellulose, and decreased the kappa number and $1 \%$ alkali solubility. In general, Increasing the $\mathrm{B} / \mathrm{L}$ ratio resulted in increased yield, viscosity, holocellulose and $\alpha$-cellulose but decreased kappa number of pulps.

Improving the chemical properties of bagasse kraft pulp could be achieved by using anthraquinone, polysulfide and sodium borohydride.

Acknowledgement : The authors thank Masr-Edfu pulp mill for providing the bagasse and Chemistry Department, Faculty of Science, Al-Azhar University for co-operation.

\section{References}

1. Rousu, P., Sustainable pulp production from agricultural waste. Anttila J. 35, 85-103 (2002) .

2. Ashori, A., Non-wood fibers- A potential source of raw material in paper making . Polymer-Plastics Techn. Eng. 10, 1133-1136 (2006) .

3. Sarwar, J.M., Nasima, C.A. and Khalidul. I.M., Characterization and eval- uation of golpata fronds as pulping raw materials. Biores, Technol. 97, 401- 406 (2006) .

4. Shatalov, A.A. and Pereira, H., Papermaking fibers from giant reed (Arundo donax L.) by advanced ecologically friendly pulping and bleaching technologies. BioRes. 1, 45-61 (2006)

5. Ali, M., Byrd, M. and Jameel, H., Soda-AQ pulping of cotton stalks. Proceedings Tappi Pulping Conference, Seattle, USA (2001).

6. Courchene, C. E. Atlanta, The tried, the true and the new-getting more pulp from chips-modifications to the kraft process for increased yield. In pr-oceedings of the breaking the pulp yield barrier symposium. Tappi J. 14, 11-20 (1998) .

7. Cöpür, Y., Tozluo Tozluoglu, A. and Özyürek, Ö., Sodium borohydrate $\left(\mathrm{NaBH}_{4}\right)$ pretreatment for efficient enzymatic saccharification of wheat straw. Biores, Technol. 107, 258-266 (2012).

Egypt. J. Chem. 57, No. 5,6 (2014) 
8. Hafizoglu, H. and Deniz, I., Wood Chemistry, KTU Faculty of Forestry Progress, Trabzon (2007).

9. Lidia, T., Kaarlo,N., Penttila, A. P., Ritva, S., Antje, P. and Herbert, S., Cellulose degradation in alkaline media upon acidic pretreatment and stabilization. Carbohydrate Polymers, 100, 185-194 (2014).

10. Jiang. J. E., Extended delignification of southern pine with anthraquinone and polysulfide. Tappi J. 78 (2), 126-132 (1995).

11. Jiang. J. E., Extended modified cooking of southern pine [pinus] with polysulfide: Effects on pulp yield and physical properties. Tappi J. 77 (2), 120-124 (1994).

12. Çöpür, Y., Refining of polysulfide pulps. J. Sci. 2, 280-284 (2007).

13. Wise, L.E., “Wood Chemistry" Vol. 1-2. Reinhoid Publishing Corporation, New York, p. 36 (1952) .

14. Akgül, M. and Temiz, S., Determination of $\mathrm{Kraft}_{-} \mathrm{NaBH}_{4}$ pulping conditions of Uludağ fir (Abies bornmulleriana Mattf). Pakistan Journal of Biological Science, 9, 2493-2497 (2006).

15. Çöpür, Y. and Tozluoglu, A., Comparison of Kraft, PS, Kraft-AQ and Kraft$\mathrm{NaBH}_{4}$ pulps of Brutia pine. Biores. Technol. 99, 909-913 (2008).

16. Valeer, D.A. G., Yield increasing additives in Kraft pulping: Effect on carbohydrate retention, composition and hand sheet properties. Ph. D. Thesis. Norwegian University of Science and Technology, Faculty of Natural Science and Technology, Department of Chemical Engineering. Torendhm, Norway (2008).

17. Landmark, P., Polysulfide addition to increase delignification in Kraft pulping. Revue A. T. I. P, 22, 87-95 (1968).

18. Luthe, C. and berry, R., Polysulphide pulping of western softwoods: Yield benefits and effects on pulp . Pulp and Paper Canada, 106, 27-33 (2005).

19. Tutus, A., Ates, S., Ezici, A. C. and Deniz, I., Chemical, morphological and anatomical properties and evaluation of cotton stalks (Gossypium hirsutum 1.) in pulp industry. Scientific Research and Essay, 12, 1553-1560 (2010).

20. Çöpür, Y. and Tozluoglu, A., The effect of AQ and $\mathrm{NaBH}_{4}$ on bio-Kraft delignification. (Ceriporiopsis subvermispora) of brutia pine chips. International Biodegradation, 60, 126-131 (2007).

21. Hart, P. W., Brogden, B. N. and Hsieh, J. S., Anthraquinone pulping of kudzu (Pueraria lobata). Tappi J.15 162- 166 (1993).

22. Tutus, A., Ates, S. and Deniz, I., Pulp and paper production from spruce wood with Kraft and modified Kraft methods. African Journal of Biotechnology, 9, 1648-1654 (2010). 
23. Khristova, P., Kordasachia, O., Patt, R., Khider, T. and Karar, I., Alkaline pulping with additives of Kenaf from Sudan. Industrial Crops and Products, 15 , 229-235 (2002).

24. Khristova, P. and Karar, I., Soda-anthraquinone pulp from three Acacia nilotica subspecies. Biores. Technol. 68, 209-213 (1999).

25. Khristova, P., Kordasachia, O., Patt, R., Khider, T. and Dafaalla, S., "Alkaline pulping of some eucalypts from Sudan. Biores. Technol. 97, 535-544 (2006).

26. Ates, S., Ni, Y., Akgül, M. and Tozluoglu, A., Characterization and evaluation of paulownia elongata as a raw material for paper production. African Journal of Biotechnology, 7 , 4153-4158 (2008).

27. pettersson, E. A. K., Rangar, M. and lindstrom, M. E., Kraft cooking chara cteristics and hexenuronic acid concentration of pulps from Eucalypt and other hardwood species. Nordic Pulp and Paper Research Journal, 17 (3), 222-227 (2002).

28. Li, Z., Ma, H., Kubes, G. J. and Li, J., Synergistic effect of Kraft pulping with polysulphide and anthraquinone on pulp-yield improvement. Journal of Pulp and Paper Science, 24, 237-241 (1998).

29. Mayovsky, J., Pan-Pacific Pulp and Paper Technology Conference Proceedings, Japan Tappi, Tokyo 2 (1992).

30. Mayovsky, J., Low Kappa Kraft, Kraft-SAQ, Polysulfide, and Polysulfide SAQ Pulping and Physical Properties Comparison. M.S. Thesis, University of Washington, Seattle (1992).

31. Kleppe, P.J., A mill trial with the addition of a small amount of AQ to Kraft and polysulfide pulping. Paperi ja Puи, 9, 63-204 (1981).

32. Green, R. P. and Smith, G. C., Tappi Pulping Conference Proceedings, Tappi Press, Atlanta, 15, 79-84 (1983).

33. Fleming, G.J., Kubes, J.M. McLeod, H.I. and Bolker, S., Alkaline pulping with additives. A review. Wood Science and Technology, 14, 207-228 (1980).

34. Akgül, M., Çöpür, Y. and Temiz, S., A comparison of Kraft and Kraft-sodium borohydrate brutia pine pulps. Build. Environ, 7, 2586-2590 (2007).

35. Istek, A., and Gonteki, E., Utilization of sodium borohydride $\left(\mathrm{NaBH}_{4}\right)$ in Kraft pulping process. J. Environ. Biol. 30, 951-953 (2009).

36. Istek, A. and Ozkan, I., Effect of sodium borohydride on Populous tremula L. Kraft pulping. Turkish J. Agric. For, 32, 131-136 (2008).

37. Gülsoy, S.K. and Eroglu, H., Effect of sodium borohydride on biokraft pulping of europian black pine (pinus nigra Arn). Technology, 13 (4), 245-250 (2010). 
38. Courchene, C.E. and McDonough, T. J., Regression models to predict level of AOX generation. Ins. of Paper Sci and Technology, Project 3826, report 1, 1-22.

39. Parthasarathy, R.V., Smith, G.C., Glen, F.R., Detty, A.E. and Steffy, M., Application of anthraquinone in extending the delignification of Kraft and polysulfide pulps part1. Pulping and bleaching of mixed hardwoods. Tappi J. 2, 113-125. (1995).

40. Jameel, H., Gratzl, J., Prasad, D.Y. and Chivukula, S., Extending delignification with AQ/polysulfide. Tappi J. 9, 151-160 (1995).

41. Hakanen, A. and Teder, A., Modified Kraft cooking with polysulphide: Yield, viscosity and physical properties. Tappi J. 80, 189-196 (1997).

42. Çöpür, Y., Makkonen, H. and Amidon, T.E., The prediction of pulp yield using selected fiber properties. Holzforschung, 59, 477-480 (2005).

43. Dillen, $\mathbf{S}$. and Noreus, $\mathbf{S}$., On the influence of sulfidity and alkali charge in kraft and polysulfide pulping of scots pine. Sven. Paper, 70 (4), 122-134 (1967).

44. Lindstorm, M. and Ants, T., The effect of polysulfide pretreatment when Kraft pulping to very low kappa numbers. Nordic Pulp and Paper Research Journal, 11, 8-11 (1995).

45. Çöpür, Y., Modifying pulping process to improve the Kraft pulp yield. Abant Izzet Baysal University Journal of forestry, 20, 28-42 (2006).

46. Maria, G., The significance of liquor-to-wood ratio on the reaction kinetics of spruce sulphate pulping. Master Thesis, Karlstads Universitet, Faculty of Technology and Science, Department of Chemical Engineering, Karlstad (2007).

47. Joachimiak, K., Bocianowski, J. and Wojclak, A., The effect of liquor to wood ratio on NSSC pulp chemical composition and fiber distribution characteristic. Forestry and Wood Technology,74,161-165 (2011).

48. Tutus, A. and H. Eroglu., A practical solution to the silica problem in straw pulping. Appita J. 56, 111-115 (2003).

49. Mao, B. and Hartler, N., Improved modified Kraft cooking. Part 3: modified vapor phase polysulfide cooking. Tappi J.77(15), 149-153 (1994).

50. Biswas, D., Misbahuddin, M., Roy, U., Francis, R.C. and Bose, S. K., Effect of additives on fiber yield improvement for Kraft pulping of Kadam. Bioresource Technology, 102, 1284-1288 (2011).

(Received 20/1/2015; accepted 1/3/2015) 


\section{تعديل لب مصاص القصب المصرى المحضر بطريقة الكرافت باستخلام إضافات محسنة للناتج}

محمد بسيونى غازى ، محمد سيد ثابت ، فرج عبد الحى أحمد ومدحت السيد عيد

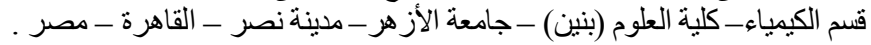

يعتبر مصاص قصب السكر من الخامات الأساسية لصناعة لب الورق في مصر.

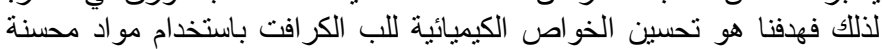

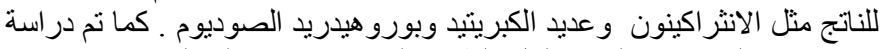

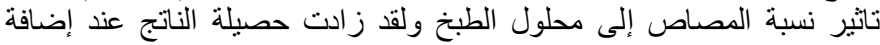

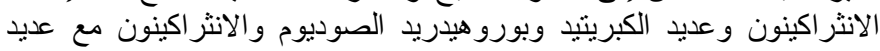

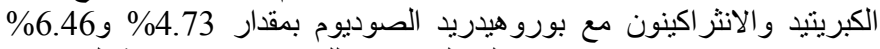

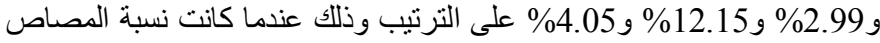

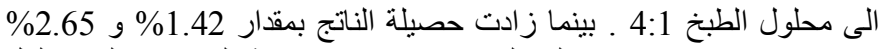

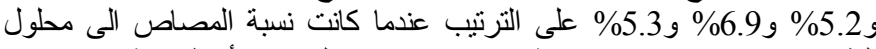

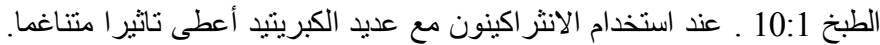

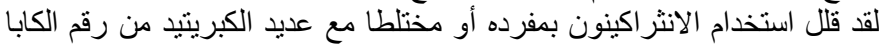

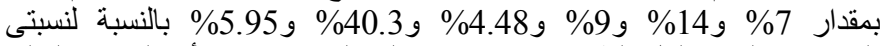

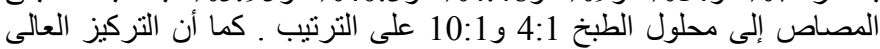

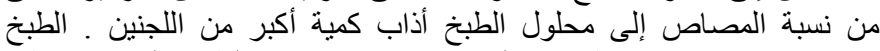

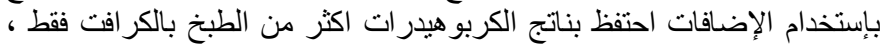

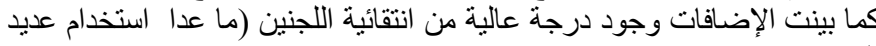

الكبريتيد). 